\title{
Fenomena Dakwah Salaf di Radio Tarbiyah Sunnah 1476 AM
}

\author{
Zaki Islami $^{{ }^{*}}$, Aef Kusnawan ${ }^{2}$, Dadan Anugrah ${ }^{3}$ \\ ${ }^{1}$ Program Studi Komunikasi dan Penyiaran Islam, Program Pascasarjana, \\ UIN Sunan Gunung Djati, Bandung \\ 2Jurusan Manajemen Dakwah, Fakultas Dakwah dan Komunikasi, \\ UIN Sunan Gunung Djati, Bandung \\ 3Jurusan Ilmu Komunikasi, Fakultas Dakwah dan Komunikasi, \\ UIN Sunan Gunung Djati, Bandung \\ *Email : rakiislami11@gmail.com
}

\begin{abstract}
Islam that is based on the Quran and al-Hadith as guidance and guidance for the Muslims have a function not only set in terms of worship but also organize people into giving demands on matters relating to employment. Work is doing an activity in order to achieve the goal, in addition to searching for sustenance but also ideals. In the work required to choose a good job and kosher, because not all of the work that God approves. Among its doctrines are back to Qur'an and Sunnah; adhere Sunni (Ahlussunnah wal Jama'ah) within its ideology which differ the other Islamic groups interpretation; anti political parties and anti-western. To hold literal interpretation in interpreting Al-Qur'an and Sunnab (Prophet tradition) is one of its concept and paradigm to avoid speculative and reasonable interpretation.
\end{abstract}

Keywords : Dakwah salaf, radio, media

\begin{abstract}
ABSTRAK
Dakwah salafiyah merupakan dakwah yang mulia dan suci, sebuah seruan yang mengajak seluruh umat manusia untuk memahami dan menjalani agama islam sebagaimana para sahabat Rasulullah, yang termasuk generasi umat saat ini, dakwah ini menyeru untuk mengikuti prinsip-prinsip mereka dalam berilmu, beramal, berjihad, berhubungan dengan penguasa, bermasyarakat, beramal ma'ruf nahi munkar, dan berbagai aktivitas kehidupan lainya, dakwah salafiyah berdiri di atas manhaj yang shohih, disinari oleh cahaya kenabian dan lentera salaful sholih serta bertumpu pada kebeningan niat, kebenaran prinsip, kemantapan landasan dan kemurnian ajaran di tengan badai fitnah serta istiqomah dalam membina umat menuju perubahan sejati, kajian ini merupakan penelitian kualitatif dengan paradigma interpretif. untuk menganlisa data metode yang digunakan adalah dengan metode fenomenologi. Pengumpulan data menggunakan teknik
\end{abstract}


wawancara dan dokumentasi, penelitian ini bertujuan untuk mengetahui makna dalwah fenomena dakwah salaf di radio tarbiyah sunnah.

Kata Kunci : dakwah salaf, media, radio

\section{PENDAHULUAN}

Dakwah salafiyah merupakan dakwah yang mulia dan suci. Sebuah seruan yang mengajak seluruh umat manusia untuk memahami dan menjalani agama Islam sebagaimana para sahabat Rasulullah, yang merupakan generasi terbaik umat ini. Dakwah ini menyeru untuk mengikuti prinsip-prinsip mereka dalam berilmu, beramal, berjihad, berhubungan dengan penguasa, bermasyarakat, beramar ma'ruf nahi munkar, dan berbagai aktivitas kehidupan lainnya. Dakwah salafiyah berdiri di atas manhaj yang shahih, disinari oleh cahaya kenabian dan lentera salafush shalih serta bertumpu pada kebeningan niat, kebenaran prinsip, kemantapan landasan dan kemurnian ajaran, sehingga dakwah salafiyah senantiasa eksis sepanjang masa dan konsisten di tengah badai fitnah, serta istiqamah dalam membina umat menuju perubahan sejati (Syamsuddin, 2009:165).

Dakwah salaf sangat berkembang pesat di Indonesia, terbukti dengan banyakan beberapa pengajian di berbagi kota di Indonesia dan di berbagai daerah, namun dakwah salaf di indoneisa tidak selalu mulus selalu ada kendala-kendala yang menghambat perkembangan dakwah salaf di Indonesia, namun para da'i-da'i yang menyerukan dakwahnya untuk kembali kepada sumber Al-quran dan Assunnah tidak pernah menyerah untuk menyampaikan suatu kebenaran.

Prinsip-prinsip dakwah salaf menyeru kepada berdakwah kepada tauhid, dakwah salafiyah mengajak kepada para da'i untuk memulai dakwahnya dengan tauhid. Ini bukan berarti berpaling dari semua konsekuensi dan aplikasi tauhid, akan tetapi menjadikan dakwah tauhid sebagai prioritas utama. Memulai dari yang paling penting kepada yang penting, melaksanakan yang waji-wajib, yang sunahsunah dan lain-lain. Wajib bagi seorang da'i memulai dakwahnya dengan tauhid, dan setiap dakwah yang tidak tegak di atas asas tauhid pada setiap tempat dan waktu, maka dakwahnya kurang dan membawa kepada kegagalan dan menyimpang dari jalan yang lurus. Dakwah tauhid adalah prinsip yang besar dalam agama Islam. Banyak da'i yang tidak mengetahui prinsip ini sehingga mereka terjerumus dalam kesyirikan, sedangkan mereka tidak menyadarinya.

Allah telah menjelaskan manhaj para rasul dalam berdakwah, Dia menjelaskannya di dalam al-Qur'an dengan penjelasan yang terbaik dan paling gamblang. Para rasul memulai dakwahnya dengan tauhid, yakni memberikan penghambaan diri kepada Allah Yang Esa, tidak untuk selain-Nya dari tuhantuhan buatan manusia lalu mempersembahkan penghambaan diri baginya disertai keyakinan bahwa ia dapat memberikan kemanfaatan, kemudharatan, memberi, menahan, memuliakan dan menghinakan. 
Para salafus shalih dari kalangan sahabat dan tabi'in menapaki jalan kenabian, mencari ilham rahasia kesatuan mereka dari kejernihan aqidah yang bersih, yang tidak ternodai oleh suatu kotoranpun. Maka jadilah mereka penguasa dunia. Allah membukakan bagi mereka pintu-pintu kebaikan dari segala penjuru. Mereka meninggikan panji-panji tauhid di bagian timur bumi dan baratnya. Semua orang yang berakal mengetahui bahwa kemenangan yang gemilang ini, yang Alloh merealisasikan melalui tangan-tangan mereka tidaklah terjadi dengan begitu saja. Itu semua terjadi dengan sebab bersandarnya mereka kepada Allah, bertawakal kepada-Nya dengan melakukan upaya-upaya yang disyari'atkan. Yaitu mereka memulai dengan yang terpenting sebelum yang penting. Titik tolak mereka dalam berdakwah dimulai dengan merealisasikan dua kalimah tauhid, "La Ilaha Illallah Muhammad Rasulullob", karena ini merupakan prinsip yang mereka diperintahkan untuk memulai dengannya (Muhammaddin, 125-146). Salah satu di antara ciri khas para pengikut manhaj salaf adalah memiliki semangat yang besar dalam menyebarkan akidah, memberikan pengajaran dan nasehat bagi umat manusia, memberikan peringatan kepada manusia dari segala bentuk bid'ah dan ajaranajaran baru, serta berupaya keras untuk membantah orang-orang yang menyimpang dan orang-orang yang jauh dari ajaran Rosul. Setiap perilaku maksiat dan penyimpangan yang dilakukan seorang hamba, pasti akan menghasilkan dampak buruk yang membahayakan, minimal kepada diri mereka para pelakunya sendiri. Apalagi jika kemaksiatan dan penyimpangan itu merupakan sesuatu yang paling dibenci oleh Allah SWT, yakni mempersekutukanya dengan segala sesuatu yang diciptakan-Nya. Tentunya kemurkaan Allah SWT melebihi kemurkaan yang disebabkan kemaksiatan dan kezhaliman lain dari seorang manusia yang masih mungkin dimaklumi dan diampuni-Nya (Willyyuddin, 2017: 13).

Keunikan manhaj dan metode dakwah Salafi menyebabkan kelompok dakwah ini mudah diterima sehingga meluas, tidak hanya di wilayah Timur Tengah, tetapi merentang jauh sampai ke Amerika, Inggris, Prancis, Belanda. Tentu saja, juga di daratan Cina, belahan Afrika Utara, Somalia, Pakistan, India, Semenanjung Malaya, dan Indonesia. Untuk kasus Indonesia, gerakan Salafi salafiyah muncul sekitar tahun 1980-an, melalui perantaraan sebagian putra-putra Indonesia yang lulus dari Universitas Islam Madinah. Mereka terpengaruh dengan para ulama salafiyah di Madinah dan mereka sedikit jumlahnya. Pengaruh yang jelas dan penyebaran yang bertambah luas dari dakwah salafiah ini juga timbul dari penyebaran dan penerjemahan kitab-kitab salafiyah ke dalam bahasa Indonesia dari para ulama salaf, baik yang lampau maupun ulama pada saat ini. Dari bukubuku itulah mereka mengenal manhaj salaf (Jawas, 2007).

Kajian ini harus berdasarkan pada hasil penelitian-penelitian terdahulu sebelumnya, agar menjadi pembeda. Oleh karena itu perlu adanya penelusuran terhadap tesis, disertasi, jurnal maupun buku pendukung terkait akan penelitian 
ini dan bentuk memetakan hal-hal yang dianggap penting guna memudahkan pemahaman mengenai telaah pustaka dalam penelitian. Berbagai penelitian untuk melengkapi penelitian saat ini, sebagai berikut:

Pertama, penelitian yang dilakukan oleh Gilang Ramadhan, UIN Sunan Gunung Djati Bandung tahun 2015 yang berjudul Pemaknaan wartawan pada peliputan peristiwa traumatik. Peneliti berusaha mengetahui pemaknaan wartawan pada peliputan peristiwa traumatik. Dijawab melalui teori fenomenologi melalui teori phenomenology theory dari Alfred Schutz. Penelitian ini menghasilkan lima dari enam informan menanggapi peristiwa traumatik sebagai peristiwa di luar batas kewajaran, sedangkan satu orang informan menganggap peristiwa traumatik sebagai peristiwa biasa saja, yang membedakan dengan kajian ini objek penelitin yang berbeda, penelitian ini lemih membahan mengenai makna dakwah salaf.

Metode yang digunakan dalam penelitian ini adalah studi fenomenologi. Metode ini menganalisis prilaku yang tampak pada diri informan yang pernah atau masih mengalami fenomena yang menjadi kajian penelitian, seperti pendapat Kuswarno dalam buku fenomenologi menyatakan.

Fenomenologi bertujuan untuk mengtahui dunia dari sudut pandang orang yang mengalaminya secara langsung atau berkaitan dengan sifat-sifat alami pengalaman manusia, dan makna yang ditempelkan padanya. Penelitian fenomenologi harus menunda proses penyimpulan mengenai sebuah fenomena. Jadi, mempertanyakan dan meneliti terlebih dulu fenomena yang tampak, dengan mempertimbangkan aspeke sadaran yang ada padanya (Kuswasno, 2009).

Sebagai disiplin ilmu, fenomenologi mempelajari struktur pengalaman dan kesadaran. Secara harfiah, fenomenologi adalah studi yang mempelajari fenomena, seperti penampakan, segala hal muncul dalam pengalaman kita, cara kita mengalami sesuatu, dan makna yang kita miliki dalam pengalaman kita (Kuswarno, 2009).

\section{LANDASAN TEORITIS}

Penelitian ini menggunakan teori fenomenologi yang digunakan dalam penelitian ini adalah teori fenomenologi menurut Alfred Schutz. Menurut Schutz, dunia sosial adalah realitas interpretif (Kusnawo, 2009).

Tindakan manusia serta segala peristiwa yang telah terjadi dianggap sebagai sebuah realitas yang bermakna. Individu bisa memberikan makna terhadap realitas tersebut. Makna terhadap sebuah realitas dalam teori ini bukan hanya makna yang berasal dari individu sendiri namun juga bersifat intersubjektif. Individu sebagai anggota masyarakat berbagi presepsi dasar mengenai realitas melalui interaksi atau sosialisasi mereka dengan anggota masyarakat lainnya (Kusnawo, 2009).

Inti pemikiran Schutz adalah bagaimana memahami tindakan sosial melalui penafsiran. Proses penafsiran dapat digunakan untuk memperjelas atau memeriksa makna yang sesungguhnya, sehingga dapat memberikan konsep 
kepekaan yang implisit. Schutz meletakkan hakikat manusia dalam pengalaman subjektif, terutama ketika mengambil tindakan dan sikap terhadap dunia kehidupan sehari-hari. Dalam hal ini, Schutz mengikuti pemikiran Husserl, yaitu proses pemahaman aktual kegiatan kita, dan pemberian makna terhadapnya, sehingga ter-refleksi dalam tingkah laku (Kusnawo, 2009).

Schutz mengawali pemikirannya dengan mengatakan bahwa objek penelitian ilmu sosial pada dasarnya berhubungan dengan interpretasi terhadap realitas. Orang-orang saling terikat ketika membuat interpretasi ini. Peneliti berusaha untuk menyamakan persepsi dengan informan. Persamaan persepsi dapat terbentuk apabila adanya komunikasi yang terus menerus sehingga peneliti dapat menemukan makna dari informan sebagai objek penelitian.

Peneliti harus menggunakan metode interpretasi yang sama dengan orang yang diamati, sehingga peneliti bisa masuk ke dalam dunia interpretasi dunia orang yang dijadikan objek penelitian. Menurut Schutz, tindakan manusia adalah bagian dari posisinya dalam masyarakat (Kusnawo, 2009)

Ada dua aspek yang dibahas dalam teori fenomenologi, yaitu: (1) Aspek intersubjektif, yakni makna subjektif yang terbentuk dalam dunia sosial oleh aktor berupa sebuah "kesamaan dan kebersamaan". Pembentukan makna dapat dihasilkan dari proses berbagi makna antar individu. Individu dalam penelitian ini adalah para informan penelitian yang berprofesi sebagai mubalig dan mempunyai pengalaman terkait masalah fenomena dakwah di kalangan salafi. (2) Aspek historis, yaitu tindakan yang berorientasi pada waktu. Ada dua hal yang dilihat dari aspek historis, yaitu motif tujuan (in order to motive) dan motif alasan (because motive). Motif tujuan merupakan motif yang dimiliki oleh informan untuk mencapai tujuan tertentu ketika mereka menafsirkan dan melakukan sebuah tindakan. Motif alasan merupakan pijakan atau pemahaman yang melatarbelakangi informan sehingga membentuk pemahaman tersendiri dalam menafsirkan tindakan tersebut (Kusnawo, 2009).

Pada tataran teoritis, Schutz memetakan beberapa sifat penting pengetahuan akal sehat dan kognisi ini, yaitu:

Pertama, bahwa pengalaman masa lalu tidak bisa menjadi penuntun yang bisa diandalkan bagi masa kini. Jika demikian, objektivitas dan tipikalitas objek-objek dan peristiwa-peristiwa sehari-hari dipahami berdasarkan penerimaan begitu saja (taken-for-granted).

Kedua, yang penting dari konteks ini adalah konsep bahwa konstruksi (atau pembentukan) objek-objek alamiah dan sosial mau tidak mau mesti disempurnakan melalui pembaruan tanpa akhir 'sintesis-sintesis pengidentifikasian (syntheses of identification). 
Ketiga, Schutz berpendapat bahwa semua objek dunia sosial dibentuk dalam kerangka 'kekeluargaan dan keakraban' yang disediakan oleh 'stok pengetahuan yang dimiliki' yang asal-usulnya bersifat sosial.

Keempat, stok konstruksi-konstruksi sosial ini dipertahankan dalam bentuk yang khas. Pengetahuan khas yang dipakai pelaku untuk menganalisis dunia sosial memang tidak begitu tepat dan bisa direvisi, tetapi di dalam sikap sehari-hari yang di dalamnya konstruksi-konstruksi berfungsi sebagai sumber programatik pengorganisasian tindakan-pertanyaan seperti kebenaran dan kegunaan konstruksi ini masih belum bisa dijawab.

Kelima, meskipun perspektif, biografi, dan motivasi yang berbeda mengarahkan pelaku untuk memiliki pengalaman yang tidak identik terhadap dunia, tetap saja mereka dapat menganggap pengalaman mereka identik untuk semua maksud praktis' (Sobur, 2013).

Dari perspektif ini, pengamat ilmiah berurusan dengan cara memaknai dan menjadikan dunia sosial bermakna. Fokus kajiannya dicurahkan pada cara anggota-anggota dunia sosial memahami dan menindaklanjuti objek pengalaman mereka seolah-olah objek pengalaman tersebut merupakan benda-benda yang berdiri sendiri dan terlepas dari diri mereka (Sobur, 2013).

Stanly Deetz menyimpulkan tiga prinsip dasar fenomenologis. Yang pertama pengetahuan ditemukan secara langsung dalam pengalaman sadar. Kita akan mengetahui dunia ketika berhubungan dengan pengalaman sendiri. Yang kedua yakni makna benda terdiri dari kekuatan benda dalam kehidupan seseorang. Bagaimana kita berhubungan dengan benda menentukan maknanya bagi kita dan yang terakhir bahasa merupakan kendaraan makna. Kita mengalami dunia melalui bahasa yang digunakan untuk mendefinisikan dan mengekspresikan dunia itu.

Berdasarkan teori fenomenologi Afred Schutz, penelitian ini akan menelusuri pemahaman, pemaknaan, dan pengalaman mubalig radio tarbiyyah Sunnah tentang dakwah salaf. Diharapkan dalam penelitian ini dapat memperoleh gambaran mengenai peliputan peristiwa.

\section{HASIL DAN PEMBAHASAN}

Pada bagian ini akan dipaparkan hasil dan temuan penelitian, penulis menghasilkan beberapa fakta yang mampu menggambarkan beberapa hasil penemuan di lapangan mengenai fenomena dakwah di kalangan salafi, hasil penelitian ini didapatkan dari para informan saat wawancara mendalam yang dilakukan oleh penulis, keterangan yang dimasuk di sini adalah berupa pengalaman, pemahaman dan pemaknaan mubalig dan mustami tentanf fenomena dakwah di kalangan salafi.

Dalam mendeskrifsikan data dan penyajian, seluruh data primer berapa hasil wawancara dengan beberapa Ustadz yang berkompeten dalam bidang dakwah khususnya tentang dakwah salaf, berdasarkan hasil wawancara, penulis 
menemukan beberapa fakta tentang pemahaman mubalig dan mustami mengenai fenomena dakwah di kalangan salafi, pengalaman mubalig dan mustami mengenai dakwah di kalangan salafi, dan yang terakhir pemaknaan mubalig dan mustami mengenai fenomena dakwah di kalangan salafi.

\section{Pengalaman Mubalig dan Mustami di Radio Tarbiyah Sunnah Tentang Dakwah Salaf}

Yang di maksud dengan dakwah adalah mengajak manusia kepada Alloh, artinya memerintahkan dan menghimbau untuk melaksanakan perintah Alloh, berupa seruan untuk beriman kepada Alloh dan semua apa yang dibawa oleh Rosul-nya. Dan ini meliputi ajaran agama seluruhnya.

Tujuan dakwah para rasul dan pengikutnya secara keseluruhan adalah menyelamatkan manusia dari gelapnya kejahilan menuju cahanya Alloh, dari kekufuran menuju pada keimaman, dari kesyirikan menuju tauhid, dan dari kesepian duani menuju kemahaluasan di akhirat. Berangkat dari ilmu dan pola piker yang benar, merupakan bekal dai akan terlihat aqidahnya, akhlaknya, tau halhal lain yang terkait dengan agamanya, tanpa pijakan yang benar, seorang dai dapat tersesat dan menyesatkan orang lain (Muhammaddin, 2005).

Dakwah salafiyah merupakan dakwah yang mulia dan suci, sebuah seruan yang mengajak seluruh umat manusia untuk memahami dan menjalani agama islam sebagaimana para sahabat Rasulullah, yang termasuk generasi umat saat ini, dakwah ini menyeru untuk mengikuti prinsip-prinsip mereka dalam berilmu, beramal, berjihad, berhubungan dengan penguasa, bermasyarakat, beramal ma'ruf nahi munkar, dan berbagai aktivitas kehidupan lainya, dakwah salafiyah berdiri di atas manhaj yang shohih, disinari oleh cahaya kenabian dan lentera salaful sholih serta bertumpu pada kebeningan niat, kebenaran prinsip, kemantapan landasan dan kemurnian ajaran di tengan badai fitnah serta istiqomah dalam membina umat menuju perubahan sejati (Syamsudin, 2009).

Seperti yang telah di jelaskan Beni Sarbeni tentang pengalam penoloakn dakwah salaf dimungkinkan kebanyakan orang tidak tau, karena kalau seseorang tau tentang dakwah salaf dia akan merasakan ke indahan dakwah salaf, karena manhaj salaf adalah manhaj yang benar sesuai apa yang di ajarkan oleh Rasul dan para sahabat, ustadz beni memaparkan lebih dalam lagi tentang tentang pangalam penolakan dakwah salaf yang awal-awalnya menolak lambat laun kita jelaskan, karena dakwah yang kita bawakan adalah dalil Al-Quran, Sunnah, Penjelasan para sahabat dan perkataan para ulama ahlul Sunnah (Wawancara Ustadz Beni Sarbeni).

Sebagaimana yang dialami Rasullullah ketika mengajak dakwah kepada tauhid niscaya akan menghadapi musuh-musuh yang tidak henti-hentinya untuk memadamkan cahaya tauhid di muka bumi ini, telah menjadi sunnatullah, Alloh 
telah menetapkan adanya musuh-musuh yang senang tiasa menghalangi dakwah tauhid dan upaya-upaya untuk menegakkan syarit islam. Mereka bisa datang dari kaum kafir ataupun datang dari kaum munafiqin yang memakai baju islam yang merasa terusik kepentingannya dan khawatir terbebongkar kedok dan syubhatsyubhatnya (Muhammaddin, 2005).

Begitu juga dakwah yang dilakukan oleh para ulama pewaris para nabi, yang selalu mendakwahkan untuk memurnikan tauhid serta menegakkan Sunnah Rasulullah, diantara mereka adalah syech Muhammad bin Abdul Wahab yang telah berupaya memurnikan tauhid umat serta mengajak mereka untuk menegakkan syariat islam, namun musuh-musuh dakwah beliau tidak rela terhadap apa yang beliau lakukan.

Seperti yang di jelaskan oleh Abu Haidar mengenai pengalaman penolakan dakwah salaf, dakwah apapun yang kita sampaikan pastinya ada pikah-pihak yang menolak, jangkan dakwah salaf, dakwah yang di sampaikan oleh nabi Muhammad SAW masih ada banyak yang menolak dan menentang terhadap dakwah beliau, tetapi yang kita harus lakukan adalah bersabar dan itu adalah termasuk Sunnah Rasul, dimana pun ada dakwah disitulah pasti ada penentangan dan penolakan. Termasuk yang dialami oleh para Nabi (Wawancara Ustadz Abu Haidar AsSundawy).

Abu Haidar pun memaparkan lebih jelas, jadi yang pertama harus tetap sabar dan yang keuda teteap istiqomah mendokan dan mendakwahi mereka dengan beragam cara, kadang di sampaikan ayat, di sampaikan hadist dan pesanpesan para ulama salaf, tetap masih mereka tidak bisa menerima, tapi di dakwahi dengan cara lain seperti dengan menunjukan kemuliaan akhlak dengan pendekan dari aspek sosial, bermuamalah dengan mereka, pokoknya berbagai macan cara yang baik dan benar dan tidak terlarang secara syar'i (Wawancara Ustadz Abu Haidar As-Sundawy).

Menolak dakwah berarti menolak kebutuhan untuk mendapatkan persetujuan orang lain terhadap apa yang diklaim sebagai kebenaran islam, tidak menuntuk persetujuan orang lain atau berarti menyatakan klaim itu subjektif, partikularis atau relative secara mutlak, karena itu tidak berlaku bagi orang lain selain perbuatan klaim itu sendiri.

Hal ini pun Lano senada dengan Abu Haidar salah satu mustami di radio Tarbiyah Sunnah, mengenai pengalaman penolakan dakwah salaf, yang pertama doakan saja, mungkin mereka belum mengenal secara benar tentang dakwah salaf, dan mereka terbawa isu-isu oleh media mengenai dakwah salaf itu seperti teroris dan di perburuk citranya oleh orang-orang yang tidak menyukai dakwah salaf, tetapi sebagai kaum muslimin harus saling mengingatkan dengan cara yang baik untuk menjelaskan dakwah salaf yang sebenarnya (Wawancara Lano, Salah Satu Mustami). 
Joni pun membagikan pengalamannya tentang dakwah salaf namul hal ini berbeda dengan apa yang di jelasakna oleh Lano, awalnya saya ingin bertobat dari riba, akan tetapi ada beberapa teman saya yang mengarahkan ke dakwah salaf, dan ini pengajian yang saya cari-cari untuk memperbaiki kehidupan ini, karena dakwah salaf apa yang di sampaikan ustadznya selalu ilmiyah dan tidak pernah menyampaikan pendapatnya akan tetapi selalu merujuk kepada Al-Qur'an dan Sunnah sesuai pemahaman salaful sholeh (Wawancara Joni, Salah Satu Mustami).

Pada awalnya istilah salafi tidak terlalu populer dan tidak indentik dengan suatu kelompok tertentu. Istilah ini di populerkan oleh Nashiruddin Al-Bani sekitar tahun 1980 di mandianah, pengikut pemikiran Al-Bani ini belakngan dikenal dengan sebutan jamaah salafi.

Dalam pandangan al-Bani, salafi adalah gerakan pemurnian ajaran islam mengampanyekan dan memberantas segala sesuatu yang di anggap bid'ah. Meskipun tujuan dan orientasi ajaran ini tidak jauh berbeda dengan wabahi, namun al-Bani tidak menggunakan istilah wahabi karena dianggap kurang tepatdan terkesan menuju satu tokoh tertentu (Muhammadin, 2005).

Pemurnian yang dilakukan al-Bani sebenarnya hampir sama dengan Muhammad bin Abdul Wahab. Keduanya sama-sama memperjuangkan pemahaman literal dan tekstual terhadap Al-Quran dan hadist. Al-Quran dan Hadist dipahami secara sempit dan kaku, bahkan mereka tidak mau menggunakan hadist dhoif dalam beramal dan mencukupkan diri dengan hadist shahih saja.

Namuh hal yang berbeda di jelasakan oleh Lano salah satu pendengar radio Tarbiyah Sunnah tentang pengalaman dakwah salaf, awalnya dari yuporia pemuda hijrah di Al-Latif dan kajian merebak dimana-mana, dimana banyak momenmomen musisi yang hijrah, seiring berkembangnya waktu dimana saya mencari kajian-kajian yang lebih tepat dan akhirnya menemukan pengajian mengenai dakwah salaf di masjid Cipagnti, kota Bandung(Wawancara Lano, Salah Satu Mustami).

Di tengan kelompok salafi, daftar bidah menjadi semakin banyak dan panjang. Wahabi hanya memberants ziarah kubur, tawasul, maulid nabi, dan amaliyah lainya, sementara salafi lebih dari itu, mereka memahami fenomena modern juga harus juga bagian dari bidah dan harus di jauhi, dilihat dari semangat dan agenda yang diusung, kedua gerakan ini memiliki misi dan agenda yang sama. Walaupun sebagian kelompok salafi tidak mau menggunakan istilah wahabi.

Seperti yang di jelaskan oleh Beni Sarbeni terkait pengalaman dakwah salaf dengan identik sebutan wahabi. Sering kali dakwah salaf ini di identikan dengan wahabi, pertama isu wahabi itu di munculkan dengan sangat luas oleh penjajah inggris demikian pula dengan orang-orang syiah karena ketidak sukan terhadap dakwah salaf(Wawancara Ustadz Beni Sarbeni). 
Beni Sarbeni pun memaparkan lebih jelas mengenai keindentikan dakwah salaf dengan wahabi, lebih jelasnya karena penjajah inggris merasa terganggu dengan dakwah salaf, dan yang paling menonjol dari dakwah salaf ialah dakwah tentang akidah, dan diantara dakwah akidah tidak boleh berloyalitas terhadap orang-orang kafir, dan konsep ini sangat mengganggu para penjajah sehingga mengangkat isi wahabi, memang ada tokoh di 2 abad hijriyah dan dia seorang khwarij yang di fatwakan oleh ulama-ulama sebagai kelompok sesat, tapi sekarang isu wahabi itu di sandarkan kepada syech Muhamammad bin Abudul Wahab, seorang tokoh ahlulsunnah wal jamaah(Wawancara Ustadz Beni Sarbeni).

Salafi merupakan ideology yang mengajurkan untuk kembali sepenuhnya kepada teladan orang-orang terdahulu, biasanya merujuk kepada Nabi, Sahabat, dan Ulama-Ulama salafulsholeh. Idiologi ini juga menyerukan penghaspusan terhadap tibunan-tibunan masa lalu, tahayul, dan taklid buta kepada preseden hukum atau mazhab pemikiran hukum tradisional, oleh karena itu salafi mengajak untuk menghidupkan kembali penggunaan ijtihad atau pemikiran hukum independen dengan kembali kepada sumber aslinya yaitu Al-Quran dan Sunnah.

Di tengan kelompok salafi, daftar bidah menjadi semakin banyak dan panjang. Wahabi hanya memberants ziarah kubur, tawasul, maulid nabi, dan amaliyah lainya, sementara salafi lebih dari itu, mereka memahami fenomena modern juga harus juga bagian dari bidah dan harus di jauhi, dilihat dari semangat dan agenda yang diusung, kedua gerakan ini memiliki misi dan agenda yang sama. Walaupun sebagian kelompok salafi tidak mau menggunakan istilah wahabi.

Seperti yang di jelaskan oleh Beni Sarbeni terkait pengalaman dakwah salaf dengan identik sebutan wahabi. Sering kali dakwah salaf ini di identikan dengan wahabi, pertama isu wahabi itu di munculkan dengan sangat luas oleh penjajah inggris demikian pula dengan orang-orang syiah karena ketidak sukan terhadap dakwah salaf (Wawancara Ustadz Beni Sarbeni).

Beni Sarbeni pun memaparkan lebih jelas mengenai keindentikan dakwah salaf dengan wahabi, lebih jelasnya karena penjajah inggris merasa terganggu dengan dakwah salaf, dan yang paling menonjol dari dakwah salaf ialah dakwah tentang akidah, dan diantara dakwah akidah tidak boleh berloyalitas terhadap orang-orang kafir, dan konsep ini sangat mengganggu para penjajah sehingga mengangkat isi wahabi, memang ada tokoh di 2 abad hijriyah dan dia seorang khwarij yang di fatwakan oleh ulama-ulama sebagai kelompok sesat, tapi sekarang isu wahabi itu di sandarkan kepada syech Muhamammad bin Abudul Wahab, seorang tokoh ahlulsunnah wal jamaah (Wawancara Ustadz Beni Sarbeni).

Salafi merupakan ideology yang mengajurkan untuk kembali sepenuhnya kepada teladan orang-orang terdahulu, biasanya merujuk kepada Nabi, Sahabat, dan Ulama-Ulama salafulsholeh. Idiologi ini juga menyerukan penghaspusan terhadap tibunan-tibunan masa lalu, tahayul, dan taklid buta kepada preseden hukum atau mazhab pemikiran hukum tradisional, oleh karena itu salafi mengajak 
untuk menghidupkan kembali penggunaan ijtihad atau pemikiran hukum independen dengan kembali kepada sumber aslinya yaitu Al-Quran dan Sunnah.

\section{Pemahaman Mubalig dan Mustami di Radio Tarbiyah Sunnah tentang Dakwah Salaf}

Islam yang dibawakan Rasulullah merupakan agama dakwah, yakni agama yang membawa ajaran-ajaran untuk disampaikan kepada umat manusia, konsekuensi logis dari keberadaan islam sebagai agama dakwah, maka islam membutuhkan eksistensi dan peran dakwah. Dakwah merupakan sarana vital bagi proses perkembangan dan kemajuan islam, baik pada masa sekarang maupun masa yang akan datang, bahkan al-Faruqi menyatakan bahwa islam tidak dapat menolak dakwah islam jika islam memiliki kekuatan intelektual (Al Thalibi, 2006).

Oleh karena itu dakwah merupakan sebuah keharusan bagi umat islam. Apalagi setelah wafatnya Rasul. Kewajiban dakwah menjadi sebuah keniscayaan dan menjadi doktrin ilahi yang dinyatakan langsung di dalam Al-Quran surat AliImran ayat 104 bahwa bagi seorang muslim, dakwah merupakan keharusan untuk dilaksanakan, secara historis, kehadiran dan peran dakwah senantiasa berinteraksi dengan dinamika atau perubahan sosial yang terjadi di masayarakat.

Dalam kehidupan Rasullulah, betapa kehadiran dan peran dakwah memilik arti signifikat gai kehidupan masyarakat, dalam kehidupan sehari-sehari, masyarakat tidak hanya di perkenalkan dan diajarkan tentang bagaimana hidup bermasyarakat dan bernegara, oleh karena itu, dakwah ini memberikan kerangka berpikir yang bersifat dalam pengembangan masyarakat. Pembahasan tentang dakwah banyak memberikan macam-macam model dalam pengaplikasiannya, didalam melaksankan dakwah setidaknya mencangkup beberapa elemen pokok yaitu: prinsip dakwah, tujuan dakwah, materi dakwah dan model dakwah. Dengan terpenuhinya dasar ini tentu akan mempermudah da'i dalam melaksanakan misi islam sebagai agama rahmatan lil'alamin (Al Thalibi, 2006).

Istilah salafi atau salafiyah menurut bahasa adalah telah lalu, kata salaf juga bermakna seseorang yang telah mendahului dalam berilmu, iman, keutamaan dan kebaikan. Ibnu Manzhur mengatakan bahwa salaf berarti orang yang mendahului anda, baik dari bapa maupun orang-orang terdekat yang lebih tua(Chozin, 2013: 1-25).

Menurut Abu Haidar As Sundawy Mengapa kita harus mencontoh para salaf? Karena merekalah generasi terbaik umat Islam. Mereka adalah orang-orang yang sentiasa menjalankan agama sesuai dengan bimbingan Rasulullah dan Rasulullah sendiri dalam hadis menjamin mereka sebagai generasi terbaik. Maka, dalam menjalankan agama, kita harus mencontoh mereka sehingga selamat dari kesesatan (Wawancara Abu Haidar As-Sundawy). 
Perlunya mencontoh praktik keagamaan generasi salaf ini karena umat Islam telah banyak mempraktikkan ajaran agama yang telah tercampur dengan berbagai bentuk bid'ah, khurafat, syirik dan tahhayul Salah satu penyebab utamanya karena umat Islam tidak lagi menjaga amalan keagamaan seperti salaf as-salih. Kembali kepada ajaran Al-Qur'an dan Sunnah adalah satu-satunya cara untuk memelihara manusia dari pada segala kesilapan dan dosa dalam mengamalkan agama, maka dari itu dakwah salah selalu mengajak kepada ajaran kemurnian dan yang seseui apa yang telah di contohkan oleh Nabi Muhammad.

Abu Haidar pun memaparkan lebih jelas, jadi yang pertama harus tetap sabar dan yang keuda teteap istiqomah mendokan dan mendakwahi mereka dengan beragam cara, kadang di sampaikan ayat, di sampaikan hadist dan pesanpesan para ulama salaf, tetap masih mereka tidak bisa menerima, tapi di dakwahi dengan cara lain seperti dengan menunjukan kemuliaan akhlak dengan pendekan dari aspek sosial, bermuamalah dengan mereka, pokoknya berbagai macan cara yang baik dan benar dan tidak terlarang secara syar'i (Wawancara Abu Haidar AsSundawy).

Menolak dakwah berarti menolak kebutuhan untuk mendapatkan persetujuan orang lain terhadap apa yang diklaim sebagai kebenaran islam, tidak menuntuk persetujuan orang lain atau berarti menyatakan klaim itu subjektif, partikularis atau relative secara mutlak, karena itu tidak berlaku bagi orang lain selain perbuatan klaim itu sendiri.

Seperti yang di jelasakan oleh Lano mengenai pemahaman dakwah salaf, dakwah salaf adalah dakwah yang di bawakan oleh nabi Muhammad SAW, para sahabat dan para tabi'in, mengacu kepada penjelasan yang benar sesuai dengan apa yang di pahami oleh nabi Muhammad SAW.

Salaf yaitu mereka tiga generasi pertama dan paling utama dari umat islam, yaitu para sahabat mereka yang hidup sebagai muslim pada masa Nabi, pernah bertemu dengan beliau, serta wafat sebagai muslim, tabi'in mereka yang hidup di masa sahabat dan wafat dalam keadaan muslim.

Salafi adalah sebuah gerakan dakwah yang sama artinya dengan gerakan dakwah Ahlul Sunnah wal Jama'ah, gerakan dakwah ini sudah mulai dari Rasulullah, lalu terus berlajut dan mempertahankan eksistensinya sehingga menjelang akhir zaman kelak. Salafi adalah sebutan utama untuk orang yang menyatakan diri sebagai muslim yang berupaya mengikuti ajaran Al-Qur'an dan Hadist, sesui dengan pemahaman ulama salaf (Haroz, 2013: 2).

Akan tetapi hal ini jelaskan oleh Abu Haidar banyaknya da'i yang salah dalam memahami dakwah salaf, yang perlu dilakukan oleh da'i mengklarifikasi poin-poin terlebih dahulu, bagian-bagian yang keliru harus di benarkan dengan pemahaman yang benar, tetapi yang lebih penting adalah harus dipahami apa yang dimaksud dengan salafi dan bagaimana yang dimaksud rujuk kepada aqidah manhaj salaf dan itu yang perlu dijelaskan, dan kalau itu sudah dijelasakn lalu 
dipahami setidaknya mengurangi kesalah pahaman terhadap dakwah salaf, kalau pun ada kesalahan pahaman dalam poin-poin tertentu kita harus meluruskan pemahaman mereka (Wawancara Abu Haidar As-Sundwy).

Dari uraian tersebut dapat dipahami bahwa salafi adalah arus pemikiran yang mendapatkan nash-nash syariah berbagai macam pikiran baik secara metode maupun sistem, yang senang tiasa komitmen terhadap petunjuk Nabi dan petunjuk para sahabat baik secara keilmuan, pemahaman dan pengalaman, menolak berbagai manhaj yang menyelisihi petunjuk tersebut, baik terjait ibadah maupun keadaan syariat.

Imam al-Safarini mengatakan bahwa yang dimaksud mazhab salaf ialah apa yang berjalan di atasnya para sahabat yang mulia, orang-orang yang mengikuti mereka dengan baik seperti tabi;in, tabiut tabi'in, serta para imam islam yang diakui keimanan mereka dan dikenal besar perannya dalam islam serta diterima ucapannya oleh kaum muslimin generasi demi generasi, bukan mereka yang tertuduh dengan kebid'han, atau dikenal sengan julukan yang tidak diridhoi seperti khawarij, rafidhah, qodariyah, murji'ah, jahmiyah, mu'tazilah dan sebagianya (Maknun, 2011).

Akan tetapi dakwah salaf selalu di kaitkan dengan pemahaman wahabi, hal ini akan di paparkan oleh Abu Haidar mengenai permasalah ini, seperti yang telah di jelasakan dalam sejarah ke islaman, bahwa syech Muhammad bin Abdul Wahab sangat intens medakwahkan aqidah salaf, dan salah satu efek yang muncul orangorang yang menyimpang dari dakwah salaf terhantam, seperti fenomena perbuatan syrik, minta-minta ke kuburan, bukan jiarah kuburannya yang dilarang, malah syech Muhammad bin Abdul Wahab sendiri mengajurkan untuk jiarah kebur, tetapi yang di soroti oleh syech Muhammad bin Abdul Wahab adalah yang meminta-minta ke kuburan, tetapi banyak orang yang merasa tersinggung lalu di generalisir oleh pihak-pihak yang tidak menyukai dakwah syech Muhammad bin Abdul Wahab bahwa beliau anti atau melarang umat muslim berjiarah kubur, padahal faktanya tidak seperti itu(Wawancara Ustadz Abu Haidar As-Sundawy).

Abu Haidar pun menambahakan mengenai dakwah salaf yang selalu di pojokan dengan kata wahabi, syech Muhammad bin Abdul Wahab menjelaskan banyak penyimpangan-penyimpangan dalam aspek aqidah yang di ingkari oleh banyak umat manusia, seperti sebagian manusia mengingkari sifat-sifat Allah yang berada di atas arsy padahal Al-Quran dan Hadist yang menjelaskan seperti itu, dan itu bukan pendapat atau ijtihadnya sendiri, melainkan penjelasan dari para ulama salaf sebelumnya, maka dari itu banyak orang yang tersinggung oleh dakwah syech Muhammad bin Abdul Wahab, maka yang di pojokan oleh sebagian orang adalah syech Muhammad bin Abdul Wahab atas ketidak sukaan terhadap dakwah beliau, yang memojokan dakwah beliau tidak berani memojokan aqidah salaf sesat, karena salaf itu sesuatu yang benar dan di akui oleh banyak kalangan, karena salaf 
itu sendiri adalah sahabat, tabi'in, dan tabiut tabi'in (Wawancara Ustadz Abu Haidar As-Sundawy).

Gerakan salafi berdiri di atas prinsip-prinsip yang kokoh dan benar, sehingga siapapun yang berpegang teguh dengannya maka jaminan selamat dari kesesatan, kebid'ahan dan kebatilan. Prinsip-prinsip yang kokoh yang dipegang teguh manhaj salaf banyak sekali, prinsip dalam hal aqidah, dalam ibadah, dalam bermuamalah dan prinsip dakwah dalam dakwah.

Sumber aqidah adalah Al-Qur'an dan Hadist yang shohih dan ijma dari ulama salaful shalih. Sumber rujukan yang memahami aqidah dalam manhaj salaf hanya terbatas pada tiga, Al-Qur'an, Hadist, da Ijma salaful shalih. Aqidah dalam agama islam adalah perkara yang ghaib, yakni yang tidak dapat diketahui dengan Sunnah dan ijma ahlul Sunnah karena ijma mereka ma'sum, yang menjadi tolak ukur dan patokan dalam menjelaskan persoalan tauhid kepada manusia adalah AlQur'an dan As-sunnah tanpa membuat kebid'ahan (Chozin, 2013).

Dalam memegang prinsip ini, lebih lanjut mereka berpegang teguh pada pemahaman sahabat dalam berinteraksi dengan nash-nash agama dan mengambil interaksi mereka dalam menganalisis dan menyimpulkan kandungan Al-Qur'an dan Sunnah, karena mereka secara langsung menimba ilmu dan mengambil kaidah tafsir dari Rasullah SAW. Salafi menolak dengan tugas setiap takwil yang diusung oleh kalangan akhli kalam dalam berinteraksi dengan nash-nash, karena manhaj ahli kalam menjadikan akal sebagai asas untuk mengukur dan menilai kebenaran nash, bila nash agama cocok dengan logika nash tersebut diambil dan bila tidak cocok harus di palingkan kepada makan lain yang sesuai dengan logika mereka (Chozin, 2013).

\section{Makna Mubalig dan Mustami di Radio Tarbiyah Sunnah tentang Dakwah Salaf}

Adapun salafi, maka itu adalah nisbat kepada manhaj salaf, dan ini adalah penisbatan yang baik kepada manhaj yang benar, dan bukan suatu yang baru dari madzhab yang baru, syeckul Islam Ibu Tamiyyah mengatakan "bukan merupakan aib bagi yang menampakan madzhab salaf yang menisbatkan dirinya kepadanya, bahkan wajib menerima yang demikian itu dari madzhab salaf tidak lain kecuali kebenaran (Jawas, 2008).

Istilah salaf bukan istilah baru, istilah tersebut digunakan sejak zaman nabi, salaf tidaklah menunjukan kepada satu golongan, tetapi menunjukan kepada orang-orang yang berpegang tueguh kepada Al-Quran dan As-Sunnah menurut pemahaman yang benar. Karena umat ini sudah terpecah belah dan yang selamat hanya satu pemahaman, seperti yang telah Rasul Sabdakan "ketahuilah, sesungguhnya orang-orang sebelum kalian dari kalangan ahlul kitab telah berpecah menjadi 72 golongan. Sesungguhnya umat islam akan berpecah belah menjadi 73 golongan, 72 golongan tempatnya di neraka dan hanya satu golongan di dalam surga, yaitu Al-Jama'ah (Al Thalibi, 2006). 
Sebagian orang menyangka, dari apa yang mereka ketahui dan mereka menyelewengkan arti ketika disebutkan istilah salafiyyah, bahwa salafiyyah adalah lebel baru atau istilah madzhab baru bagi kelompok islam yang baru melepaskan diri dari lingkaran jama'ah Islamiyah yang utuh.

Sangkaan ini sama sekali tidak benar, karena salafiyyah maksudnya adalah islam dengan kesempurnaan dan keumumannya, yakni islam yang dibersihkan dari pengaruh budaya-budaya klasik dan warisan-warisan dari banyak kelompok dan sekte yang dimasukan kedalam islam. Jadi salafiyyah adalah islam dengan kesempurnaan dan keumumannya, yakni islam yang berdasarkan Al-Qur'an dan As-Sunnah menurut pemahaman salaf yang terpuji (Ardiansyah, 2013).

Sangkain ini sesungguhnya hanyalah muncul dari angan-angan kaum yang ingin menghindari kalimat yang baik dan berkah, yang akarnya menancap kuat dalam sejarah umat ini hingga sampai ke generasi pertama (Shabat). Sampaisampai mereka mengira bahwa kata salafiyyah adalah hasil dari gerakan pembaharuan yang di bawakan oleh Jamaluddin al-Afgahani dan Muhammad bin Abdul Wahab pada masa penjajahan Inggris di Mesir.

Dan orang yang mengucapkan hal ini atau yang menyebarkan adalah orang yang tidak mengetahui sejarah dari kata istilah salaf yang sanadnya bersambung kepada generasi salaful sholeh, baik dari sisi makna, akar kata, maupun waktu. padahal ulama-ulama terdahulu mensifati setiap orang yang mengikuti pemahamannya sahabat dalam masalah aqidah dan manhaj denan istilah salafi.

Dari penjabaran makna salafi, baik dari sisi pengertian maupun penisbatan kepadanya, Nampak jelaslah kesalahan para penulis dan pemikir yang menganggap penisbatan diri kepada salaful shalih, da'i-da'i menyeru kepadanya, bermanhaj dengan manhajnya, dan memperingatkan orang-orang yang menyelisihi pendak rasul dan sebagain dari kelompok-kelompok yang banyak meracuni ukat islam. Bahkan mereka menganggap bahwa mengingatkan umat dari manjah yang menyimpang adalah penyebab perpecahan (Syamsuddin, 2015).

Abu Haidar pun menjelasakn mengenai makna dakwah salaf, pertama dakwah salaf adalah mengajak manusia untuk memahami islam sesuai dengan generasi para sahabat, berdasarkan penjelasan para ulama, kenapa demikian, karena itu adalah perintah Allah dan Rasul, Islam itu wajib di pahami melalui pemahaman para sahabat, seperti yang telah Allah Firmankan dalam surat AtTaubat ayat 100 dan hadist tentang wajibnya mengikuti para sahabat (Wawancara Ustadz Abu Haidar As-Sundawy).

Abu Haidar pun memaparkan lebih dalam mengenai makna dakwah salaf, Jadi dakwah salaf adalah mengajak manusia untuk memahami Al-Quran dan AsSunnah menurut pemahaman generasi salaful sholeh, kalau perumpamaannya orang tidak mengikuti generasi salaful sholeh dengan cara apalagi Al-Quran dan As-Sunnah akan dipahami, apakah akan dipahami oleh pikiran masing-masing itu 
adalah suatu yang salah, atau menurut kacamata filsafat atau dengan ilmu yang sedang berkembang sekarang, itu semua sesuatu yang keliru jika Al-Quran dan As-Sunnah dipahami dengan ilmu yang berkembang sekarang, pemahaman AlQuran dan As-Sunnah yang benar adalah sesuai dengan pemahaman salaful sholeh karena mereka dalam bimbingan nabi Muhammad, itu lah hakikat dan makna dari dakwah salaf (Wawancara Ustadz Abu Haidar As-Sundawy)

\section{PENUTUP}

Prinsip-prinsip dakwah Salafiyah terdapat beberapa ciri khas diantaranya memerangi perkara bid'ah, tahayul, syirik dan kurafat, dari yang besar sampai kepada yang sekecil- kecilnya yang tidak ada contoh dari Rasul atau tidak ada dalil nash dari al- Qur'an dan al- Sunnah. Selain dari itu ciri khas dakwah Salafiyah memerangi dakwah hizbiyah dan fanatik golongan yang bertentangan dengan manhaj yang shahih yang sesuai dengan dakwah yang telah dipraktikkan oleh salafus shalih.

Untuk membentuk masyarakat ideal, sebagaimana tuntunan al-Qurean dan al Sunnah, harus didahului dengan membangun individu-individu sebagai komponen penyusun masyarakat itu sendiri. Dari individu yang baik akan terbangun keluarga yang baik dan dari keluarga yang Islami akan terbentuk masyarakat yang Islami pula.

\section{DAFTAR PUSTAKA}

Ab Majid, M. K. H. (2003). Fanatik dan taksub dalam Islam: Analisis pandangan al-Qaradawi. Jurnal Usuluddin, 18, 25-36.

Ardiansyah, A. (2013). Pengaruh Mazhab Hanbali Dan Pemikiran Ibnu Taimiyah Dalam Paham Salafi. Journal Analytica Islamica, 2(2), 246-261.

Chozin, M. A. (2013). Strategi Dakwah Salafi di Indonesia. Jurnal Dakwah, 14(1), 1-25.

Dermawan, A. (2013). Dialektika Dakwah, Politik Dan Gerakan Keagamaan Kontemporer (Telaah Pemikiran Nasir al-Din al-Albani dan Pengaruhnya Terhadap Pembentukan Salafy Kontemporer). Jurnal Dakwah, 14(2), 159175.

Haron, Z., \& Hussin, N. (2013). A Study of the Salafi Jihadist Doctrine and the Interpretation of Jihad by Al Jama'ah Al Islamiyah. Kemanusiaan: The Asian Journal of Humanities, 20(2).

Jawas, Y. A. Q. (2008). Mulia dengan manhaj salaf. Pustaka at-Taqwa.

Kuswarno, E. (2009). Fenomenologi: metode penelitian komunikasi: konsepsi, pedoman, dan contoh penelitiannya. Widya Padjadjaran. 
Maknun, L. (2011). Sejarah Generasi As-Salaf As-Salih Yayasan Nida'ul Fithrah Di Surabaya Tahun 2000-2010 (Doctoral dissertation, UIN Sunan Ampel Surabaya).

Muhammaddin, M. Prinsip-Prinsip Dakwah Salafiyah. Jurnal Ilmu Agama UIN Raden Fatah, 15(1), 125-146.

Syamsuddin, Z. A. (2015). Membedah Akar Fitnah Wahhabi: Buku Putih Dakwah Salafiyah.

Al Thalibi, A. A. (2006). Dakwah salafiyah dakwah bijak: meluruskan sikap keras dai salafi (Vol. 1). Hujjah Press.

Sihabuddin, M. A. (2018). Komunikasi Dakwah Bagi Pemurnian Akidah Ummat. Jurnal Komunikasi Islam dan Kebumasan (JKPI), 2(1), 52-61.

Syamsudin, Z. A. (2009). Buku Putih Dakwah Salafiyah. Pustaka Imam Abu Hanifah, Jakarta.

Sobur, A. (2013). Filsafat Komunikasi: Tradisi Dan Metode Fenomenologi. Bandung: Remaja Rosdakarya.

Sihabuddin, M. A. (2018). Komunikasi Dakwah Bagi Pemurnian Akidah Ummat. Jurnal Komunikasi Islam dan Kebumasan (JKPI), 2(1), 52-61.

Yani, H. A. (2005). Bekal menjadi Khatib dan Mubaligh. Gema Insani.

Willyuddin A.R. Dhani, Bahaya.!!! Tradisi Kemusyrikan Di Sekitar Kita, (Bandung: Abu Hanifah Publishing ,2007), h.13

Yazid bin Abdul, Q. J. (2006). Syarah'Aqidah Ablussunnah wal Jama'ah. Niaga Swadaya. 
Z. Islami, A. Kusnawan, \& D. Anugrah 